\title{
THE PENETRABILITY OF RABBIT OVA TREATED WITH ENZYMES OR ANTI-PROGESTERONE ANTIBODY: A PROBE INTO THE NATURE OF A MAMMALIAN FERTILIZIN
}

\author{
J. W. OVERSTREET AND J. M. BEDFORD \\ Departments of Obstetrics and Gynecology, and Anatomy \\ Cornell University Medical College, New York, N.Y. 10021, U.S.A.
}

(Received 26th November 1974)

\begin{abstract}
Summary. The acrosome reaction of rabbit spermatozoa, an essential prerequisite for penetration of the zona, occurs usually in the vicinity of the egg, suggesting that the rabbit egg may produce a factor akin to the 'fertilizin' of some invertebrates. Specific inactivation of such a factor should render eggs impenetrable and possibly point to the nature of a 'fertilizin' in mammals.

Rabbit eggs with granulosa cells removed were treated for different periods with trypsin, chymotrypsin, neuraminidase or anti-progesterone antiserum, and then transferred alone, or together with control eggs (one group labelled with fluorescein isothiocyanate), to the oviducts of inseminated recipients. Three hours later the eggs were recovered and the experimental and control groups were compared for penetration of the vitellus and for numbers of spermatozoa within the perivitelline space or in the zona pellucida. None of these treatments affected the penetrability of the zona pellucida significantly since the number of spermatozoa within treated eggs in any one experiment was always comparable to that of untreated eggs exposed to the same fertilization environment.

If there is a specific substance emanating from or present on the surface of the rabbit egg which induces the acrosome reaction, its activity seems unaffected by trypsin or chymotrypsin; the charged radicals of $\mathrm{N}$-acetyl neuraminic acid or local concentrations of progesterone do not appear to be involved.
\end{abstract}

\section{INTRODUCTION}

Until recently, studies of invertebrate species have formed the basis for much of the discussion of sperm-egg interaction in general, including that of mammalian gametes. It has recently become apparent, however, that there are significant differences in some aspects of mammalian and invertebrate fertilization, e.g. the need for capacitation of mammalian spermatozoa (Chang, 1951; Austin, 1951) before the acrosome reaction can occur (Bedford, 1969), and the 
mode of incorporation of the sperm head into the vitellus (see Colwin \& Colwin, 1967; Yanagimachi \& Noda, 1970; Bedford, 1970, 1972). Other critical preliminaries to penetration in mammals involving sperm head membrane fusion and loss of the acrosomal content, the acrosome reaction (Barros, Bedford, Franklin \& Austin, 1967), appear to be similar to those in the classic invertebrate species (see Dan, 1967; Colwin \& Colwin, 1967).

In echinoderms and annelids, the acrosome reaction is known to be initiated by an active agent, fertilizin, emanating from the egg coat (Metz \& Morrill, 1955; Tyler, 1956), but little is known of the physiological induction of the mammalian acrosome reaction, other than the experimental observation that capacitation seems to be a prerequisite for this event to occur. Follicular and other biological fluids will induce morphological changes in the acrosome (Barros \& Austin, 1967; Yanagimachi, 1969; Bedford, 1969) but it is not known whether these are the elements which initiate the reaction at the site of fertilization in vivo, since washed eggs can be readily fertilized. The existence in mammals of active egg substances possessing sperm-agglutinating (Bishop \& Tyler, 1956) or sperm-immobilizing properties (Thibault \& Dauzier, 1960) homologous with the fertilizins of invertebrate eggs has been proposed, but their role in the initiation of the acrosome reaction is obscure.

Although hamster spermatozoa have sometimes been observed undergoing the acrosome reaction independently in vitro (Yanagimachi, 1966), rabbit spermatozoa with acrosomes which have undergone the reaction usually appear in close association with the egg mass, i.e. in the interstices of the granulosa layer or at the zonal surface (Bedford, 1968, 1969). These and other data have prompted the suggestion that there may be a fertilizin-like substance emanating from the mammalian egg which initiates the events of the acrosome reaction (Bedford, 1968, 1969; Austin, Bavister \& Edwards, 1973). It is difficult to recover sufficient mammalian eggs to test satisfactorily for the presence of a fertilizin-like substance in the 'egg water'. The present experiments were, therefore, designed in an attempt to neutralize or destroy the hypothetical fertilizin-like activity of the egg with specific agents, thereby removing the trigger for the acrosome reaction and rendering the egg impenetrable or less receptive than control eggs. Logically, the nature of an effective treatment would provide some indication of the character or identity of the fertilizin.

\section{MATERIALS AND METHODS}

Eggs were recovered from the oviducts of donor rabbits either following injection of 100 i.u. HCG or after superovulation had been induced by a series of three daily subcutaneous injections of 0.5 i.u. porcine FSH (Sigma) in $1 \mathrm{ml}$ saline followed by an intravenous injection of 100 i.u. HCG (Pregnyl: Organon) on the 4th day. The donors were killed by an overdose of sodium pentobarbitone 13 to $14 \mathrm{hr}$ after the injection of HCG and the eggs were recovered by flushing the excised oviduct with physiological saline. The cumulus oophorus was dispersed by a 5 -min exposure of the egg mass to $0.1 \%$ bovine testicular hyaluronidase (Sigma), and the corona radiata was removed by gentle manual shaking for $2 \mathrm{~min}$ in a small test-tube containing $1 \mathrm{ml}$ of $2 \%$ sodium citrate. In 
each experiment, the eggs of two donors were assigned to two groups and were transferred to $1-\mathrm{ml}$ microdishes containing $0.5 \mathrm{ml}$ active (experimental) enzyme or heat inactivated (control) enzyme solutions.

In eight experiments, ova were exposed to bacterial neuraminidase (Clostridium perfringens, type VI: Sigma) at $37^{\circ} \mathrm{C}$ for $30 \mathrm{~min}$ to $\mathrm{I} \mathrm{hr}$. The enzyme solution was prepared at a concentration of $0.5 \mathrm{mg} / \mathrm{ml}$ or $1.0 \mathrm{mg} / \mathrm{ml}$ in tissue culture medium (TC 199), gassed with $\mathrm{CO}_{2}(\mathrm{pH} \mathrm{6.5)}$.

In another series of experiments, bovine pancreatic trypsin (type III: Sigma) in concentrations of $0.001 \%$ or $0.005 \%$ in TC 199 (sixteen experiments) or chymotrypsin in similar concentrations (two experiments) was used, and the eggs were incubated at $37^{\circ} \mathrm{C}$ for 5 to $10 \mathrm{~min}$. Initial trials indicated that such protease-treated eggs could not be recovered after instillation into the recipient oviduct, and it was therefore necessary to prevent the continued action of bound trypsin or chymotrypsin by incubating the eggs in a mixture of the specific irreversible inhibitors of chymotrypsin and trypsin, 2-nitro-4-carboxyphenyl-N,N-diphenyl-carbamate (NCDC) (Shaw \& Springinghorn, 1967) and $\mathrm{N}$ - $\alpha$-p-tosyl-L-lysine chloromethyl ketone HCL (TLCK) (Erlanger \& Edel, 1964) respectively. The inhibitors were prepared in Tyrode's solution at a concentration of $10^{-4} \mathrm{M}$ and, after enzyme treatment, the eggs were incubated in $0.5 \mathrm{ml}$ of this solution for $30 \mathrm{~min}$ at room temperature. Aliquots of the enzyme solutions heated to $100^{\circ} \mathrm{C}$ for $10 \mathrm{~min}$ were used for incubation of the control eggs and, with this exception, the experimental and control populations were handled similarly.

Living eggs may be labelled with fluorescein isothiocyanate (FITC) without affecting their transport, penetrability or fertilizability (Overstreet, 1973). Such eggs may be transferred in a mixed population with unlabelled eggs and so a critical comparison of the penetrability of the two gamete populations may be made in the same oviduct. After treatment with the enzymes and enzyme inhibitors, therefore, the eggs were re-washed in TC 199 and experimental or control eggs were labelled with FITC in alternate trials. The experimental and control groups of eggs were mixed and transferred in about $0.01 \mathrm{ml}$ saline into the oviducts of twenty-three recipient females by way of the fimbrial ostium. These recipients had been inseminated intratubally with 1 to $5 \times 10^{6}$ washed ejaculated spermatozoa 12 to $15 \mathrm{hr}$ earlier. Eggs were recovered $3 \mathrm{hr}$ after transfer, and when they had been mixed, experimental and control groups were identified according to the presence of the fluorescent marker. The perivitelline spermatozoa in each egg were counted and, after fixation and staining with lacmoid (Chang, 1952), the number of spermatozoa associated with the zona pellucida was scored. To test the possibility that, when mixed, the control eggs might influence sperm penetration of enzyme-treated eggs, two experiments involving instillation of the latter alone into the oviducts of inseminated recipients were performed for each treatment.

\section{The effect of anti-progesterone antiserum on sperm-egg interaction}

Freshly recovered eggs were denuded of granulosa cells in the manner previously described. In each experiment, $50 \%$ of the eggs recovered from two donors was transferred to a depression slide containing $0.5 \mathrm{ml}$ rabbit anti- 
progesterone antiserum (supplied by Dr R. J. Ryan, Mayo Glinic: $1 \mathrm{ml}$ undiluted serum bound approximately $75 \mathrm{ng}$ progesterone). The remaining (control) eggs were transferred likewise to $0.5 \mathrm{ml}$ normal rabbit serum. All eggs were incubated in moist chambers at $37^{\circ} \mathrm{C}$ for 1 to $2 \mathrm{hr}$, and then washed twice in saline. In alternate trials, either experimental or control eggs were conjugated to FITC. Mixed populations of experimental and control eggs were transferred into the oviducts of nine recipients which had been inseminated intratubally with 1 to $5 \times 10^{6}$ washed ejaculated spermatozoa 12 to $15 \mathrm{hr}$ earlier. Subsequently, to check whether or not the antibody-treated eggs were being penetrated because of an influence from the control eggs in the mixed situation, groups of eggs similarly treated with antiserum (supplied by Dr K. S. Sundaram, Population Council: $1 \mathrm{ml}$ undiluted serum bound approximately $700 \mathrm{ng}$ progesterone) were instilled separately into one oviduct of a recipient, the control eggs being placed into the contralateral oviduct. In all cases, the eggs were recovered 3 to $4 \mathrm{hr}$ after transfer and, when mixed groups had been used, the two groups were identified according to the presence of the fluorescent marker. The perivitelline spermatozoa in each egg were counted before the eggs were fixed in acetic alcohol and stained with lacmoid. After staining, the numbers of spermatozoa associated with the zona pellucida and the state of the fertilizing spermatozoon were noted.

\section{RESULTS}

\section{The influence of enzyme treatment on the penetrability of the zona pellucida}

Treatment with neuraminidase at a concentration of $0.5 \mathrm{mg} / \mathrm{ml}$ for $30 \mathrm{~min}$ or $1 \mathrm{hr}$ had no effect on the penetration of spermatozoa into the zona pellucida or on the fertilizability of the eggs denuded of cumulus cells (Table 1). When the enzyme concentration was $1.0 \mathrm{mg} / \mathrm{ml}$, however, no vitelline penetration was observed, and although the zona was visibly unchanged, the vitellus was often shrunken and appeared degenerate. Nevertheless, neither concentration of the enzyme depressed the number of spermatozoa subsequently passing

Table 1. Penetration of spermatozoa into the zona pellucida of rabbit eggs treated with bacterial neuraminidase

\begin{tabular}{|c|c|c|c|c|c|c|c|c|c|c|}
\hline \multirow{3}{*}{$\begin{array}{c}\text { Exp. } \\
\text { No. }\end{array}$} & \multirow{3}{*}{$\begin{array}{l}\text { Incubation } \\
\text { time (min) }\end{array}$} & \multirow{3}{*}{$\begin{array}{c}\text { Enzyme } \\
\text { conc. } \\
(\mathrm{mg} / \mathrm{ml})\end{array}$} & \multicolumn{4}{|c|}{ Experimental eggs } & \multicolumn{4}{|c|}{ Control eggs } \\
\hline & & & \multirow{2}{*}{$\begin{array}{l}\text { No. of } \\
\text { eggs } \\
\text { recovered }\end{array}$} & \multirow{2}{*}{$\begin{array}{c}\text { No. of } \\
\text { eggs } \\
\text { fertilized }\end{array}$} & \multicolumn{2}{|c|}{$\begin{array}{l}\text { Mean no. } \\
\text { of sperm. }\end{array}$} & \multirow{2}{*}{$\begin{array}{l}\text { No. of } \\
\text { eggs } \\
\text { recovered }\end{array}$} & \multirow{2}{*}{$\begin{array}{l}\text { No. of } \\
\text { eggs } \\
\text { fertilized }\end{array}$} & \multicolumn{2}{|c|}{$\begin{array}{l}\text { Mean no. } \\
\text { of sperm. }\end{array}$} \\
\hline & & & & & $\begin{array}{c}\text { in } \\
\text { p.v.s. }\end{array}$ & $\begin{array}{c}\text { in } \\
\text { zona }\end{array}$ & & & $\begin{array}{c}\text { in } \\
\text { p.v.s. }\end{array}$ & $\begin{array}{c}\text { in } \\
\text { zona }\end{array}$ \\
\hline 1 & 30 & 0.5 & 4 & 4 & 0 & $7 \cdot 3$ & 4 & 4 & 0 & $5 \cdot 8$ \\
\hline 2 & 60 & 0.5 & 22 & 19 & $2 \cdot 3$ & 12.5 & 15 & 9 & 1.4 & $11 \cdot 1$ \\
\hline 3 & 45 & 1.0 & 2 & 0 & 0 & $15 \cdot 0$ & 1 & i & 1.0 & 14.0 \\
\hline 4 & 45 & 1.0 & 3 & 0 & 0 & 0.3 & 4 & 3 & 4.0 & $3 \cdot 0$ \\
\hline 5 & 60 & $1 \cdot 0$ & 12 & 0 & 0 & 0.7 & 6 & 0 & 0 & 0 \\
\hline 6 & 60 & 1.0 & 10 & 0 & $1 \cdot 2$ & 17.7 & 10 & 9 & $0 \cdot 4$ & $12 \cdot 5$ \\
\hline 7 & 60 & 1.0 & 8 & 0 & $2 \cdot 8$ & 23.5 & 7 & 6 & 3.0 & $17 \cdot 3$ \\
\hline 8 & 60 & 1.0 & 10 & 0 & 1.3 & $17 \cdot 4$ & 8 & 5 & 1.5 & $15 \cdot 2$ \\
\hline
\end{tabular}

Experimental and control eggs were transferred as a mixed population into the oviducts of inseminated recipients and recovered $3 \mathrm{hr}$ later. Eggs of the experimental or the control group were labelled with FITC. p.v.s., perivitelline space. 


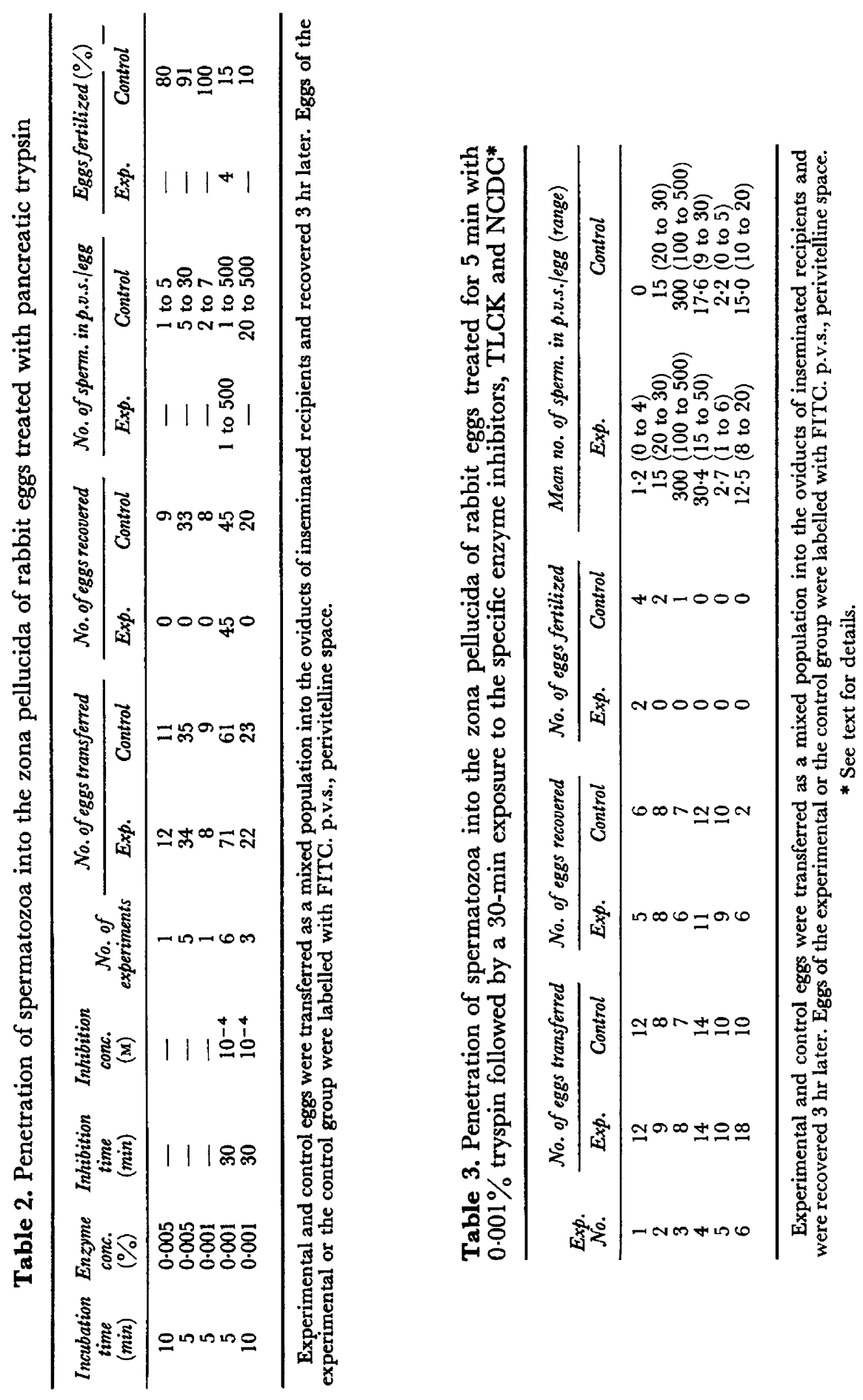




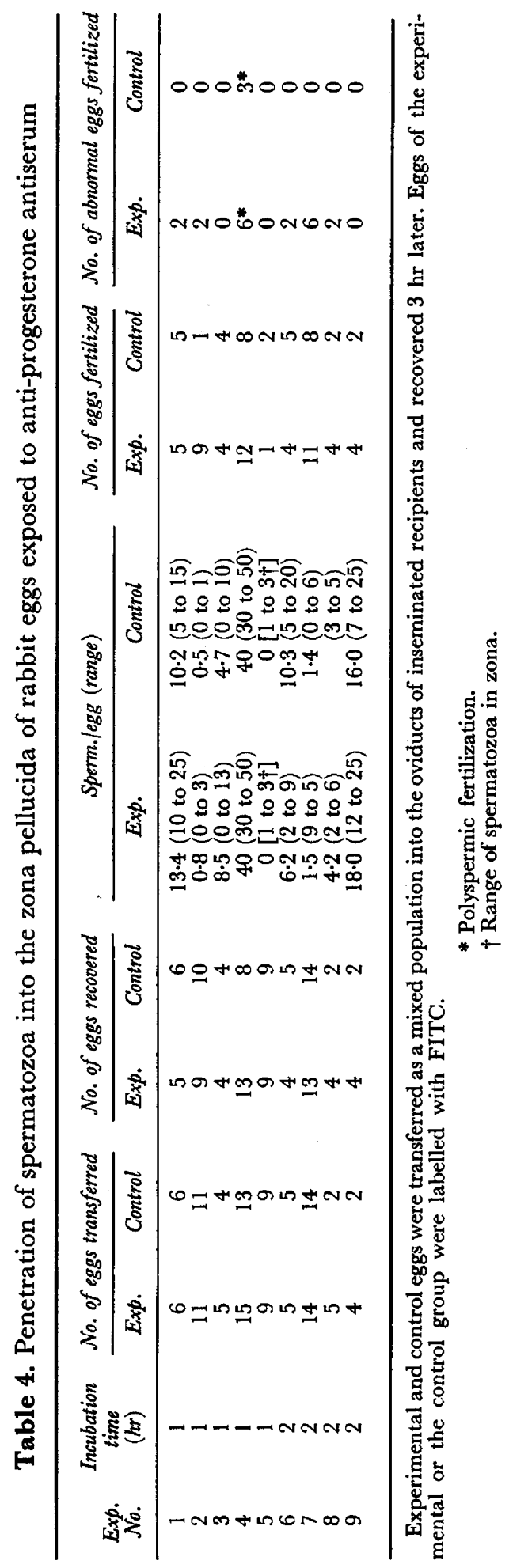


through the zona pellucida (Pl. 1, Figs 1 to 4). In eight experiments the number of spermatozoa in the perivitelline space of seventy-two experimental eggs (mean number 1.49) was not different from that in fifty-five control eggs (mean number 1.46) recovered from the same oviducts (Table 1).

When eggs were treated with trypsin or chymotrypsin, there was little or no visible change in the zona pellucida or vitellus at the time of transfer to the recipient (Pl. 2, Fig. 5), but none of these eggs could be recovered $3 \mathrm{hr}$ later unless the mildest enzyme treatment was used. In nine experiments in which none of the seventy-six treated eggs could be found, $89 \%$ of seventy-eight control eggs were recovered from the same oviducts (Table 2). The failure to recover enzyme-treated eggs was rectified by post-treatment incubation with the specific enzyme inhibitors TLCK and NCDC (P1. 2, Fig. 6). Thus, in the six experiments in which eggs were treated with a $0.001 \%$ trypsin solution for $5 \mathrm{~min}$ followed by incubation with the inhibitors for $30 \mathrm{~min}, 63 \%$ of seventyone experimental ova were recovered, as compared to $74 \%$ of sixty-one control ova (Table 2). In two experiments involving pre-treatment with chymotrypsin, all eggs recovered showed several perivitelline spermatozoa in each egg. In spite of frequent distortions and visible thinning of the zona pellucida in experimental cumulus-free eggs, there was no difference between the experimental and control groups in the $\%$ of eggs penetrated or in the number of perivitelline spermatozoa (Table 3; Pl. 2, Figs 7 and 8). Lower levels of vitelline penetration, however, were observed in both experimental and control groups in all instances when eggs were exposed to the enzyme inhibitors before transfer. It is unlikely that the penetration of enzyme-treated eggs was affected by the presence of control eggs in the same oviduct since in two experiments with each enzyme treatment the zona pellucida of treated eggs transferred alone was consistently penetrated by several spermatozoa.

\section{The effect of anti-progesterone antiserum on sperm-egg interaction}

The penetration of spermatozoa into the zona pellucida and vitellus was not adversely affected by prior incubation of the egg in rabbit anti-progesterone antiserum. In nine 'mixed' experiments, $83.1 \%$ of sixty-five eggs so treated were fertilized compared to $61.7 \%$ of sixty control eggs recovered from the same oviducts (Table 4). Similarly, there was never any significant difference between the antiserum-treated and control eggs with respect to the proportion penetrated or the mean number of perivitelline spermatozoa/egg (Pl. 3, Fig. 9). Subsequently, when groups of treated and control eggs were instilled separately into the contralateral oviducts of a recipient, a total of 14/15 antiserum-treated and 12/14 control eggs were penetrated in $4 \mathrm{hr}$, and there was no significant difference in the mean numbers of perivitelline spermatozoa or stage of pronuclear development in the respective groups.

There were several instances of retarded transformation of the fertilizing sperm nucleus in experimental eggs treated with the antiserum binding $75 \mathrm{ng}$ progesterone $/ \mathrm{ml}$, characterized in most cases by a failure of the sperm head to expand after incorporation into the ooplasm (Pl. 3, Figs 10 to 12). This pattern was observed in fourteen of sixty-five experimental eggs and in five of the 
nine experiments. Such an anomaly was not seen in the eggs treated with the antiserum binding $700 \mathrm{ng}$ progesterone $/ \mathrm{ml}$ or in any of the control eggs.

\section{DISCUSSION}

The reported composition of Arbacia fertilizin as a sialoprotein (Isaka, Hotta \& Kurokawa 1970), was the original stimulus for the present attempt to modify with neuraminidase and trypsin the ability of the rabbit egg to induce the acrosome reaction. Our finding of a normal penetration rate after prolonged neuraminidase treatment of eggs makes it unlikely that a molecule depending

\section{EXPLANATION OF PLATES}

\section{PLATE 1}

FIG. 1. Rabbit eggs $3 \mathrm{hr}$ after transfer to the same oviduct of an intratubally inseminated recipient. Ova treated with a 'high' concentration $(1.0 \mathrm{mg} / \mathrm{ml}$ for $1 \mathrm{hr}$ ) of neuraminidase (N) show some distortion of the zona pellucida and/or degeneration of the vitellus. Control ovum (C) has been fertilized normally. Phase contrast, $\times 225$.

Fig. 2. Neuraminidase-treated rabbit ovum ('low' concentration, $0.5 \mathrm{mg} / \mathrm{ml}$ for $1 \mathrm{hr}$ ) recovered $3 \mathrm{hr}$ after transfer to an intratubally inseminated recipient. Numerous spermaatozoa are present in the zona pellucida and perivitelline space. Phase contrast, $\times 750$.

FIGs 3 and 4 . Neuraminidase-treated rabbit ova ('high' concentration, $1.0 \mathrm{mg} / \mathrm{ml}$ for 1 $\mathrm{hr}$ ) recovered $3 \mathrm{hr}$ after transfer to an intratubally inseminated recipient. The vitellus is degenerate but spermatozoa are present in the perivitelline space (arrows). Phase contrast, $\times 500$.

\section{PLATE 2}

FIG. 5. Rabbit ova following treatment with active or heat-inactivated trypsin $(0.005 \%$ for $5 \mathrm{~min}$ ). Trypsinized ova (T) could not be recovered from recipients following egg transfer. Control ova (C) were consistently recovered from the same oviducts. Phase contrast, $\times 170$.

Fig. 6. Trypsinized $(\mathrm{T})(0.001 \%$ trypsin for $5 \mathrm{~min})$ and control $(\mathrm{C})$ rabbit ova following incubation in the enzyme inhibitors, TLCK and NCDC $\left(10^{-4} \mathrm{M}\right.$ for $\left.30 \mathrm{~min}\right)$. Phase contrast, $\times 400$.

FIG. 7. Rabbit ova recovered $3 \mathrm{hr}$ after transfer to an intratubally inseminated recipient. The ovum treated with trypsin and TLCK/NCDC (T) has a thin and expanded zona pellucida. Control ovum (C) treated with heat-inactivated enzyme and inhibitors has a normal appearance. Phase contrast, $\times 200$.

FIG. 8. Trypsinized rabbit ovum recovered $3 \mathrm{hr}$ after transfer to an intratubally inseminated recipient. Spermatozoa are present in the perivitelline space and there are pronuclei in the ooplasm (arrows). Two polar bodies were present but no fertilizing sperm tail could be distinguished. Phase contrast, $\times 500$.

\section{PLATE 3}

FiG. 9. A rabbit ovum recovered $3 \mathrm{hr}$ after transfer to an intratubally inseminated recipient. The ovum was incubated in anti-progesterone antiserum for $2 \mathrm{hr}$ before transfer. Spermatozoa are present in the perivitelline space (arrow) and in the zona pellucida. Phase contrast, $\times 400$.

FIG. 10. A recently penetrated anti-progesterone antiserum-treated rabbit ovum. The sperm tail (arrow) remains partly in the perivitelline space. Lacmoid, phase contrast, $\times 625$.

Fig. 11. A rabbit ovum treated with anti-progesterone antiserum, stained with lacmoid to show a fully developed female pronucleus $(P)$ and a condensed sperm head $(\mathbf{H})$. Phase contrast, $\times 625$.

FIG. 12. A spermatozoon which has penetrated the vitellus of an anti-progesterone antiserum-treated rabbit ovum. The sperm head $(\mathrm{H})$ remains condensed and the tail $(\mathrm{T})$ is visible. The shadowy spermatozoon (S) is present outside the vitellus in the perivitelline space. A fully formed female pronucleus was present elsewhere in the ooplasm. Phase contrast, $\times 1500$. 
PI.XTE 1
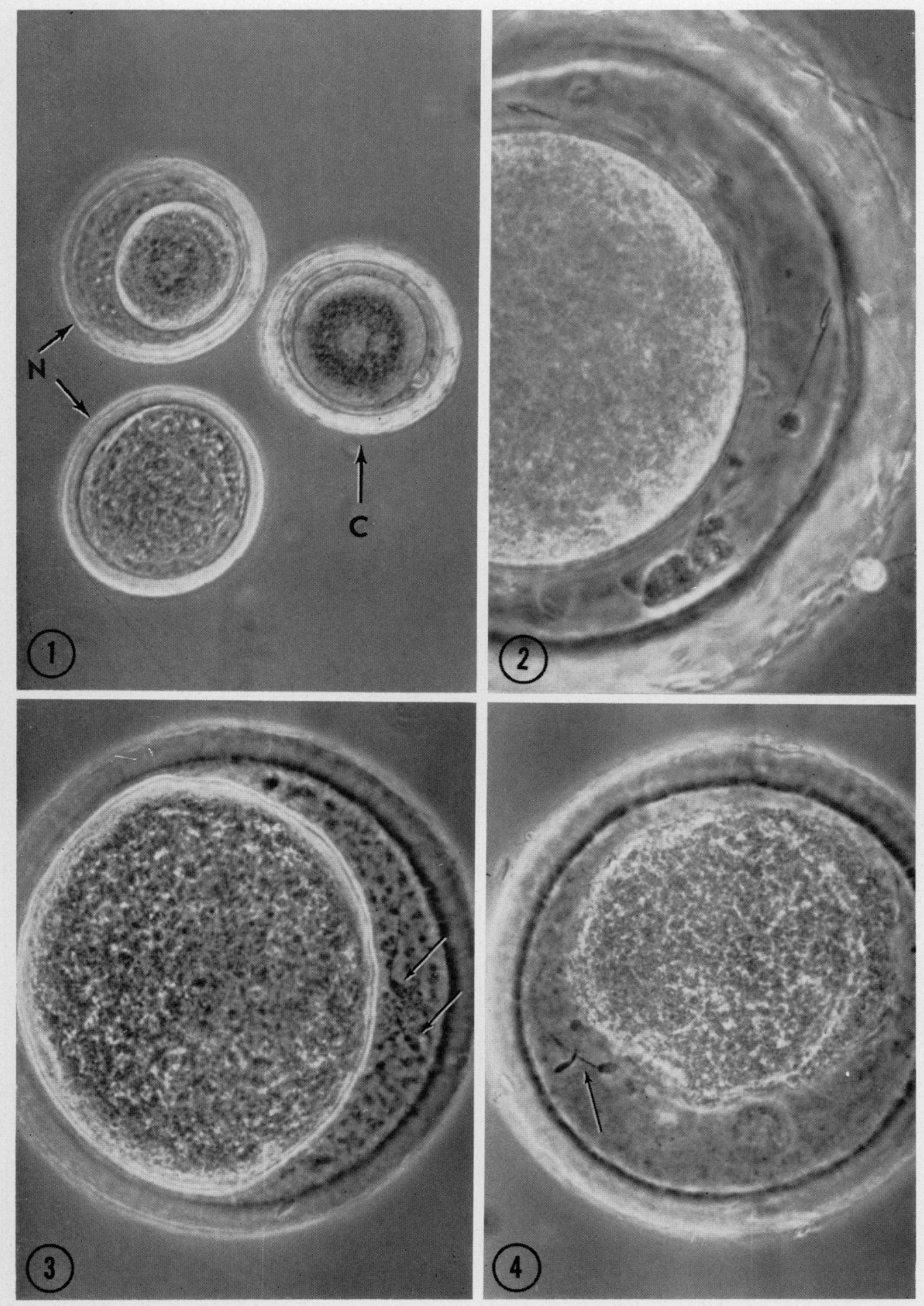

(Facing p. 280) 
PI..TTE 2
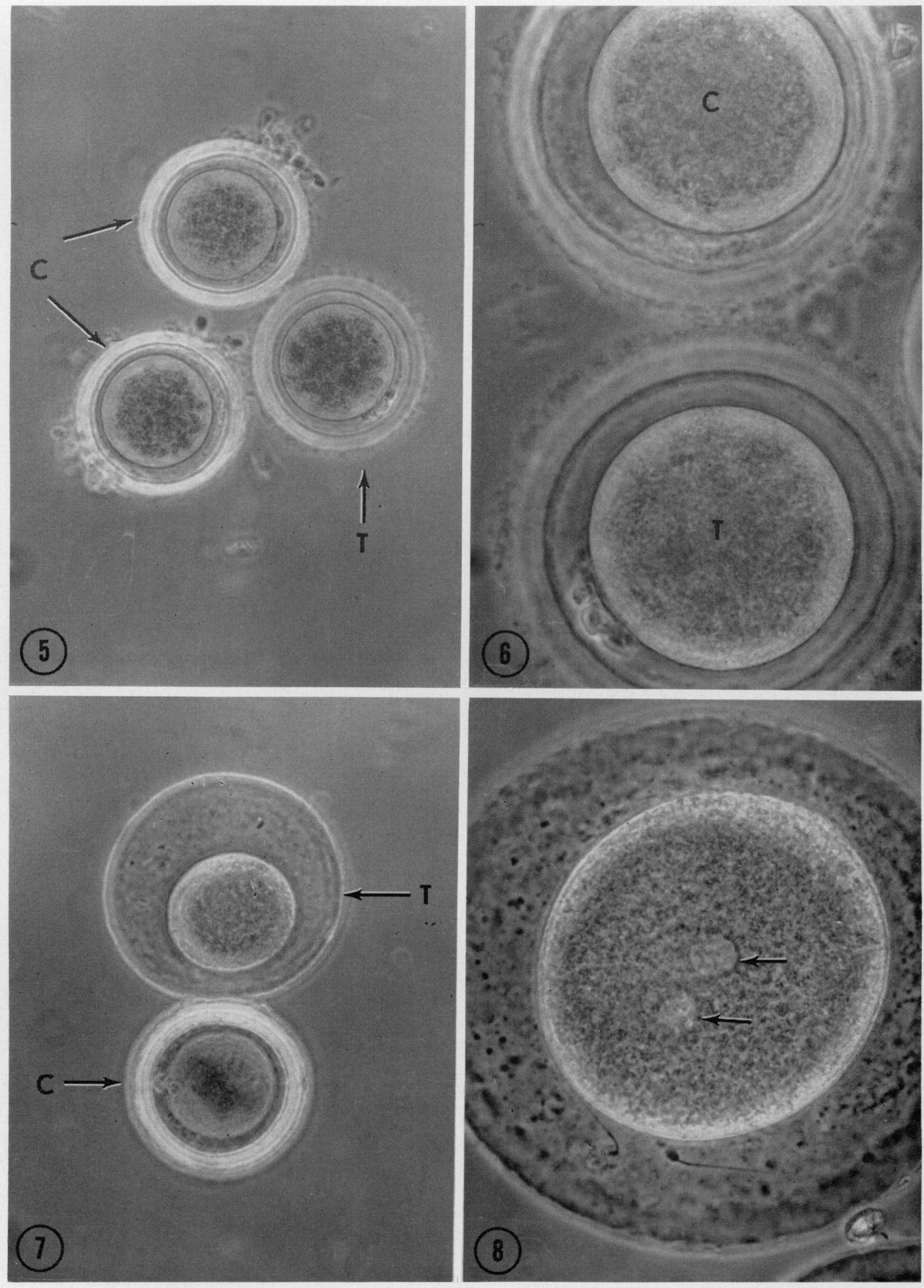
PI.ITE 3
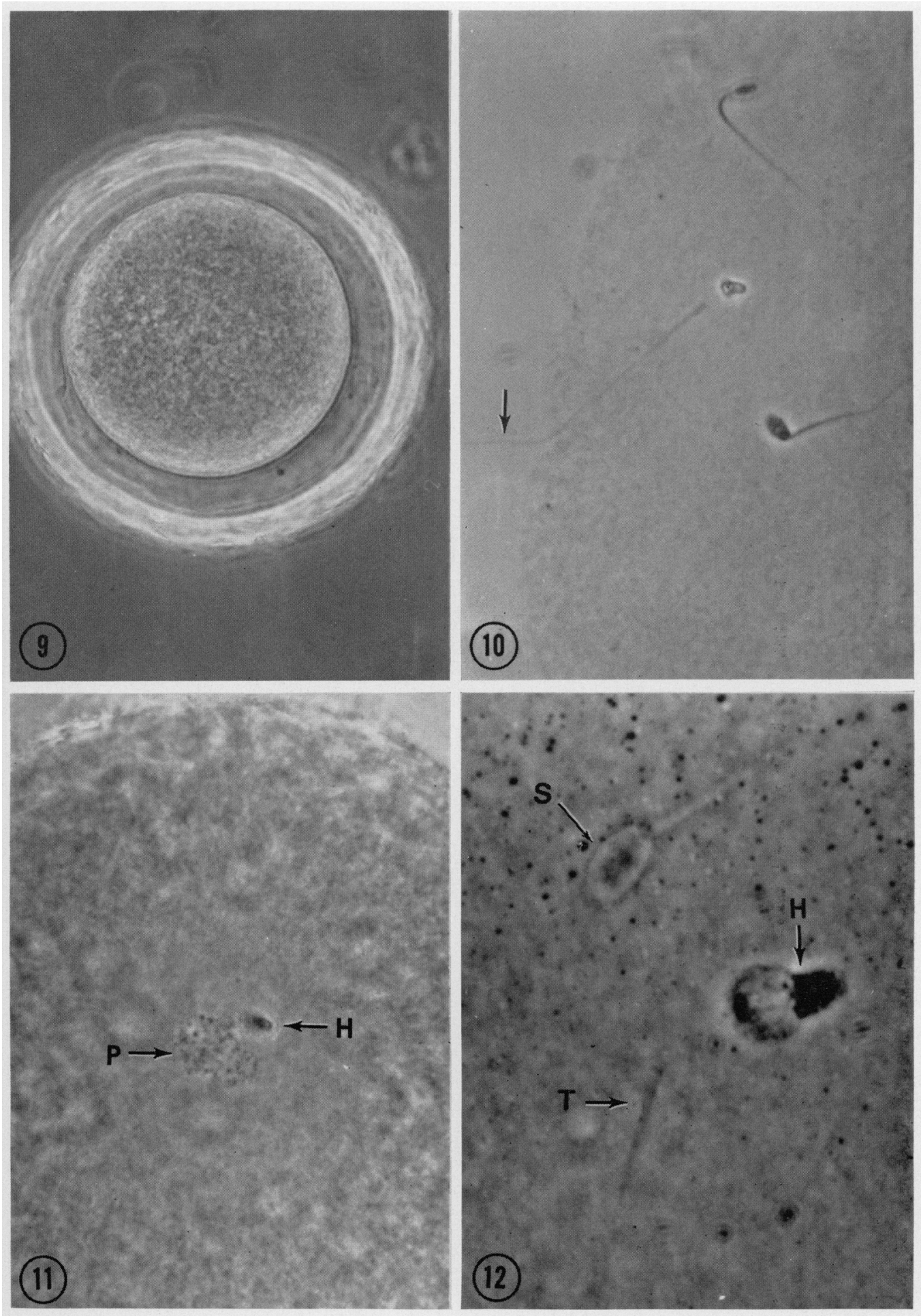
on the presence of neuraminidase-sensitive $\mathrm{N}$-acetyl neuraminic acid moieties is important for induction of the acrosome reaction in the rabbit. This finding contradicts the conclusion of Soupart \& Glewe (1965) that treatment with neuraminidase will specifically inhibit the penetrability of the rabbit zona pellucida, especially since the enzyme preparations used here $(1.0$ to 3.0 units $/ \mathrm{mg})$ were ten to thirty times more active. In the eight experiments in which neuraminidase-treated and control eggs were transferred to the same oviduct, there was no difference between the control and experimental groups in the number of spermatozoa penetrating the zona pellucida (Table 1). At the lower enzyme concentration $(0.5 \mathrm{mg} / \mathrm{ml})$, twenty-three of thirty-six experimental eggs were fertilized. The higher concentration of enzyme $(1 \mathrm{mg} / \mathrm{ml})$, though toxic to the egg, was also ineffective in reducing the level of sperm penetration into the zona pellucida.

The possibility that the hypothetical mammalian fertilizin might be a protein led us to test the effects of proteases on the penetrability of the rabbit egg. Concentrations of trypsin or chymotrypsin sufficient to produce visible thinning and distortion of the zona pellucida had no significant influence on sperm penetration, indicating that the acrosome reaction does not depend on a diffusible molecule that is trypsin- or chymotrypsin-sensitive. Ishihara \& Dan (1970) likewise found that extensive proteolytic treatment of echinoderm fertilizin did not affect its ability to induce either agglutination or the acrosome reaction of homologous spermatozoa. The results of the present manipulations indicate that alterations in the 'structure' of the rabbit zona pellucida do not necessarily affect sperm penetration, since mild trypsinization which consistently produced distortion and visible thinning of the zona had no effect on the number of spermatozoa passing through this coat (Table 3). Failure to recover treated eggs after incubation at higher enzyme concentrations (Table 2) is not surprising since the zona pellucida has been shown to be essential for survival and transport of the early zygote, and eggs without their zonae are seldom recovered after transfer to the oviduct (Moore, Adams \& Rowson, 1968; Bronson \& McLaren, 1970; Modlinski, 1970).

It has been suggested that progesterone, which is known to 'destabilize' lysosomal membranes, may play a similar role in the acrosome reaction by inducing a labile state in the acrosomal membranes (Austin et al., 1973; Edwards \& Fowler, 1970). Obviously, there are a number of quantitative uncertainties in the use of anti-progesterone antibody, but, the absence of any effect on sperm penetration following incubation of granulosa-denuded eggs for $2 \mathrm{hr}$ in a potent anti-progesterone antiserum (Table 4) makes it doubtful that progesterone, either alone or as a prosthetic group of a larger molecule, plays an important role in inducing the acrosome reaction. The work of Glass (1971) and of Hastings, Enders \& Schlafke (1972) suggests that an antibody such as that in the present experiments could penetrate at least to the vitelline surface of the treated egg.

It should be noted that the studies include at least two experiments for each treatment in which treated and control groups of eggs were placed in different oviducts. The fact that treated eggs in isolation were penetrated as often as the controls in the contralateral tube shows that the treated 
eggs did not depend for penetration on a positive influence of control eggs in the same environment. Since the zona of eggs killed by a high level of neuraminidase treatment was penetrated as often as was that of controls, it is unlikely that an acrosome reaction-inducing agent was continually secreted and thus renewed by the egg in the oviduct after treatments aimed at destroying the agent.

The anomalous expansion of the fertilizing sperm head in a number of anti-progesterone antiserum-treated eggs in which the female pronucleus had developed normally supports the idea (Thibault \& Gérard, 1970) that there is a specific mechanism of expansion of the sperm nucleus within the ooplasm independent of that which brings about dispersion of the female chromosomes. The fact that this was seen only after treatment with the serum binding $75 \mathrm{ng}$ progesterone $/ \mathrm{ml}$ and containing sodium azide $(0.1 \%)$ as a preservative, and not with the other serum which had approximately ten times more anti-progesterone activity but no such preservative, implicates azide rather than specific antibody in such suppression of sperm head expansion.

There are many facets of sperm-egg interaction in mammals that are not yet understood and the problem of deriving a clear over-all picture by experiment is complicated by what appear at present as significant differences among the major species used for such experiments. Recent work in the hamster suggests that malleable 'receptors' at the zona surface determine the success of the sperm attachment to and penetration of the zona pellucida. Whereas in the hamster these appear sensitive to trypsin (Hartman \& Gwatkin, 1971), the present studies show no such effect in rabbit eggs. The basis of the zona block to polyspermy in the hamster seems to lie in changes in such zona surface components (Barros \& Yanagimachi, 1971), but the receptivity of the rabbit zona to spermatozoa remains apparently unchanged, both qualitatively and quantitatively, after fertilization (Overstreet \& Bedford, 1974), notwithstanding changes in the character of its substance (Chang \& Hunt, 1956; Conrad, Buckley \& Stambaugh, 1971).

It is apparent that, in species such as the hamster, the acrosome reaction may occur in capacitated spermatozoa in vitro in many circumstances. If the content of the acrosome is important for fertilization, however, it seems logical that there should be some mechanism in vivo, to insure a coordinated reaction and release of acrosomal enzymes in the vicinity of the egg. The mass of the cumulus oophorus might be a source of an acrosome reaction-inducing factor either in a diffusible form or bound to the surface of the granulosa cells or their intercellular matrix since the reaction often occurs within the cumulus before sperm contact with the zona surface (Austin, 1960; Bedford, 1968). The egg itself must also possess such a factor, judged by its ready penetrability when washed free of the granulosa vestment. We have reported here that prior treatment with trypsin, chymotrypsin, neuraminidase or anti-progesterone antibody has no effect on the rate of penetration of the rabbit zona pellucida. Further experiments are needed to determine whether other reagents, e.g. carbohydrases or lipases, can modify the ability of the isolated egg to induce an acrosome reaction and thus its receptivity to capacitated spermatozoa. The possibility that the substance of the zona itself can initiate the reaction should not be ignored. 


\section{ACKNOWLEDGMENTS}

These studies were performed for the most part while the authors were members of the Department of Anatomy, and International Institute for Human Reproduction, Columbia University College of Physicians and Surgeons. They have been supported by NIH grant 03623 and by a grant from the Ford Foundation.

\section{REFERENGES}

Austin, C. R. (1951) Observations on the penetration of sperm into the mammalian egg. Aust. $\mathcal{F}$. sci. Res., Ser. B, 4, 581-589.

Austin, C. R. (1960) Capacitation and the release of hyaluronidase from spermatozoa. F. Reprod. Fert. $1,310-311$.

Austin, G. R., Bavister, B. D. \& Edwards, R. G. (1973) Components of capacitation. In The Regulation of Mammalian Reproduction, pp. 247-254. Eds. S. J. Segal, R. Grozier and P. A. Corfman. Charles G. Thomas, Springfield.

Barros, G. \& Austin, C. R. (1967) In vitro fertilization and the sperm acrosome reaction in the hamster. 7. exp. Zool. 166, 317-324.

Barros, G., Bedford, J. M., Franklin, L. E. \& Austin, C. R. (1967) Membrane vesiculation as a feature of the mammalian acrosome reaction. 7. Cell Biol. 34, C1-C5.

BarRos, C. \& YaNAGIMAchi, R. (1971) Induction of the zona reaction in golden hamster eggs by cortical granule material. Nature, Lond. 233, 268-269.

BEDFoRd, J. M. (1968) Ultrastructural changes in the sperm head during fertilization in the rabbit. Am. F. Anat. 123, 329-357.

BEDFORD, J. M. (1969) Morphological aspects of sperm capacitation in mammals. Adv. Biosti. 4, 35-50.

Bedford, J. M. (1970) Sperm capacitation and fertilization in mammals. Biol. Reprod. 2, Suppl. 2, $128-158$.

BEDFORD, J. M. (1972) An electron microscopic study of sperm penetration into the rabbit egg after natural mating. Am. F. Anat. 133, 213-253.

Brshop, D. W. \& TyLER, A. (1956) Fertilizins of mammalian eggs. F. exp. Zool. 132, 575-595.

Bronson, R. A. \& MCLaren, A. (1970) Transfer to the mouse oviduct of eggs with and without the zona pellucida. F. Reprod. Fert. 22, 129-137.

Chang, M. C. (1951) Fertilizing capacity of spermatozoa deposited into the Fallopian tubes. Nature, Lond. 168, 697-698.

CHANG, M. C. (1952) Fertilizability of rabbit ova and the effects of temperature in vitro on their subsequent fertilization and activation in vivo. F. exp. Zool. 121, 351-381.

Chang, M. C. \& Hunt, D. M. (1956) Effects of proteolytic enzymes on the zona pellucida of fertilized and unfertilized eggs. Expl Cell Res. 11, 497-499.

Colwin, L. H. \& Colwin, A. L. (1967) Membrane fusion in relation to sperm-egg association. In Fertilization, Vol. 1, pp. 295-367. Eds. C. B. Metz and A. Monroy. Academic Press, New York.

Conrad, K., Buckley, J. \& Stambaugh, R. (1971) Studies on the nature of the block to polyspermy in rabbit ova. F. Reprod. Fert. 27, 133-135.

DAN, J. C. (1967) Acrosome reaction and lysins. In Fertilization, Vol. 1, pp. 237-293. Eds. C. B. Metz and A. Monroy. Academic Press, New York.

Edwards, R. G. \& Fowler, R. E. (1970) Human embryos in the laboratory. Scient. Am. 223, 44-54.

ERLANGER, B. F. \& EDEL, F. (1964) The use of a specific chromogenic inactivator in an "all or none" assay for chymotrypsin. Biochemistry, N.Y. 3, 346-349

Glass, L. E. (1971) Transmission of maternal proteins into oocytes. Adv. Biosci. 6, 28-58.

HartMan, J. F. \& GWATKIN, R. B. L. (1971) Alteration of sites on the mammalian sperm surface following capacitation. Nature, Lond. 234, 479-481.

Hastings, R. A., Enders, A. C. \& Schlafke, S. (1972) Permeability of the zona pellucida to protein tracers. Biol. Reprod. 7, 288-296.

Isaka, S., HotTA, K. \& Kurokawa, M. (1970) Jelly coat substances of sea urchin eggs. Expl Cell Res. $59,37-42$.

IsHiHARA, K. \& DAN, J. C. (1970) Effects of chemical disruption on the biological activities of sea urchin egg jelly. Dev. Growth Diff. 12, 179-188.

METz, C. B. \& MoRrill, J. B. (1955) Formation of acrosomal filaments in response to treatment of sperm with fertilizin in Asterias and Nereis. Biol. Bull. mar. biol. Lab., Woods Hole, 109, 349.

MoDLinski, J. (1970) The role of the zona pellucida in the development of mouse eggs in vitro. F. Embryol. exp. Morph. 23, 539-547. 
Moore, N. M., Adams, C. E. \& Rowson, L. E. A. (1968) Developmental potential of single blastomeres of the rabbit egg. 7. Reprod. Fert. 17, 527-531.

Overstreet, J. W. (1973) The labelling of living rabbit ova with fluorescent dyes. F. Reprod. Fert. 32, 291-294.

Overstreet, J. W. \& Bedford, J. M. (1974) Comparison of the penetrability of the egg vestments in follicular oocytes, unfertilized and fertilized ova of the rabbit. Devl Biol. 41, 185-192.

Shaw, E. \& Springinghorn, S. (1967) Identification of the histidine residue of the active site of trypsin labelled by TLCK. Biochem. biophys. Res. Commun. 27, 391-397.

Soupart, P. \& CLewe, T. H. (1965) Sperm penetration of the rabbit zona pellucida inhibited by treatment of ova with neuraminidase. Fert. Steril. 16, 677-689.

Thibault, C. \& Dauzier, L. (1960) "Fertilisines" et fécondation in vitro de l'oeuf de lapine. C.r. hebd. Séanc. Acad. Sci., Paris, 250, 1358-1359.

Thibault, G. \& Gerard, M. (1970) Facteur cytoplasmique nécessaire à la formation du pronucleus mâle dans l'ovocyte de Lapine. C. r. hebd. Séanc. Acad. Sci., Paris, 270, 2025-2029.

Tyler, A. (1956) Physico-chemical properties of the fertilizins of the sea urchin Arbacia punctulata and the sand dollar Echinarachnius parma. Expl Cell Res. 10, 377-386.

Yanagimachi, R. (1966) Time and process of sperm penetration into hamster ova in vivo and in vitro. 7. Reprod. Fert. 11, 359-370.

YANAGIMACHI, R. (1969) In vitro acrosome reaction and capacitation of golden hamster spermatozoa by bovine follicular fluid and its fractions. 7. exp. Zool. 170, 269-280.

Yanagimachi, R. \& NodA, Y. D. (1970) Ultrastructural changes in the hamster sperm head during fertilization. 7. Ultrastruct. Res. 31, 465-485. 